\title{
Nigeria: \\ Resource Conflicts and Rurality. Implications on Heritage Assets
}

\author{
Elochukwu A. NWANKWO \\ Halilu AISHAT
}

\begin{abstract}
Since its independence in 1960, Nigeria has been ravaged by various categories of resource conflicts with consequential effects on rurality. These conflicts have caused untold hardship on rural communities in Nigeria to the extent that some of the communities have been deserted for safety elsewhere. These rural communities have valued heritage assets where they had leveraged on for meaningful socioeconomic recovery. This study was aimed at identifying these resource conflicts and their impacts on heritage assets in rural Nigeria. However, resource conflicts like Boko Haram, militancy, herdsmen, banditry, and communal conflicts were identified. Evidences show that these conflicts obliterate tangible and intangible heritage assets of rural communities in Nigeria, with correspondence effect on heritage transfer through memory loss. Effective international support among others was recommended as a possible option. This study has implications for the understanding of further effects of resource conflicts on rurality in Nigeria.
\end{abstract}

\section{Elochukwu A. NWANKWO \\ Department of Archaeology and Tourism, University of Nigeria, Nigeria \\ elochukwu.nwankwo@unn.edu.ng \\ Halilu AISHAT \\ Department of Archaeology and Tourism, University of Nigeria, Nigeria \\ aishat.halilu@unn.edu.ng \\ Conflict Studies Quarterly \\ Issue 35, April 2021, pp. 51-69}

DOI: $10.24193 / \mathrm{csq} .35 .4$

Published First Online: 05 April /2021
Keywords: Resource conflicts; heritage assets; heritage preservation; rural communities; conflict theory.

\section{Introduction}

Resource conflict has to do with all kinds of disputes with causes emanating from natural resources such as land, water, oil, gold, forest, etc. (Omur, 2015; Lababidi \& Hiba, 2016). These conflicts have taken so many dimensions in global politics. A further understanding on resource conflict will be hinged on four distinctive categories of 
resource conflict. They include: resources that are peculiar to a particular geographical setting where there is a risk of rebellion by some kind of secessionist movements; those resources that are part of national integration agenda; those that are have been metamorphosed to national projects such as mines and hydropower generating dams, oil blocks, conservation areas, etc.; and the last category has to do with the commutative impact of small scale multiple disputes like land dispute, water dispute, farm dispute, etc. (Brown \& Keating, 2015; Keating, 2015). Most of the time resource conflict emanates from struggle over resource rights. USIP (2015) defined resource right as the authority to harness and make use of natural resources. Struggle for this resource rights have caused the Nigerian nation billions of naira and loss of human lives since the last four decades.

Nigeria, as a nation, has numerous ethnic groups, with over 250 languages spoken across various cultural groups, and over 250 million populations according to 2017 World bank population statistics for nations. The nation is richly blessed with multiplicity of heritage assets (natural and cultural) that are naturally distributed across various geopolitical zones of the country (Anozie, 2002; Ofomata, 2002; Frey \& Rohner, 2007; Nwankwo, 2013). These heritage assets are those natural and cultural endowments of a people that are usually inherited by the virtue of being a member of a particular community where such heritage assets are located. Over the years, more emphasis has been given to the natural resources due to their unprecedented economic values. These natural resources include but not limited to petroleum resources, forest resources, land resources, animal resources, water resources, and mineral resources like gold, zinc, and the likes. The nature of their control and management is dependent on the existing relevant public policies and that of local regulations in some cases (Nwankwo, 2013; Abara, n.d;).

However, there have been incessant struggles over the control of these resources in Nigeria since independence in 1960 . These struggles have culminated to different kinds of conflicts with much effect on the rural population (Abomaye, et al., 2018; Goyei, 2018). Therefore, resource conflicts can be seen as struggles and clashes that emanate from the quest for the ownership and use of natural resources. Also, Klare, Levy and Sidel (2011) defined resource conflicts as violent conflicts that are motivated by the strict competition for the ownership and control of valuable natural resources. This is extended to include minerals, land, wildlife, and other natural endowments which are classified as the heritage of man in his environment.

Moreover, it is regrettable to note that quest for the ownership and control for natural resources that are of great value, have been among key determinants of existing resource conflicts in Nigeria. The nation have been ravaged with various kinds of conflicts and violent conflicts arising from the struggle for the ownership and control of natural resources that are of great economic value (Paki \& Ebienfa, 2011; Olasupo, 2013; Adelaja, 
et al., 2018). Nigeria has not fared better since the inception of these conflicts. There have been incessant killings, destructions, explosions, untold hardship, and unending security issues, among others. Also, apart from the spontaneous displacement of people from their original homes, these conflicts have cost the government of the country tons of investments and other great economic loss.

Heritage assets aid in historical reconstruction and tourism promotion, with huge implications for culture and identity promotion. They include tangible heritage assets (i.e caves, water bodies, rock shelters, forests, wildlife, rock overhangs, sacred groves etc.), intangible heritage assets (i.e., festivals, belief systems, traditional ceremonies etc.) and built heritage assets (seaports, bridges, amusement parks, recreation centers, great edifices, etc.) (Ofomata, 2002; Nwankwo, 2013; Ezenagu, 2018). This study has its major focus on tangible and intangible heritage assets. These great heritage assets are irretrievable when decimated and Nigerians cannot afford to lose these irreparable values of human history to resource conflicts. To this regard, this study was aimed at identifying these resource conflicts and their impacts on heritage assets in rural Nigeria.

\section{Background studies}

It will be imperative at this juncture to look at some related studies and reports on the subject matter. For instance, Moustafa (2006) in his study on the destruction of cultural heritages in the Middle East amidst wars notes that destruction of cultural heritages is a current concern in the Middle East. These wars took place 2001 in Afganistan, 2003 in Iraq, 2010 in Yemen, 2011 in Syria, and 2012 in Libya. He concluded that these wars led to the loss of human lives, and destruction of cultural heritages. Also, Buhari and Soetan (2018) informed that the activities of organized terrorist groups have the tendencies of inflicting a far reaching destruction on community structures and lifestyles. They also informed that Boko Haram activities which began in Nigeria in 1995 have caused most of the rural communities in north east Nigeria their indigenous values and other communal benefits. This view was supported by Adelaja, Labo and Penar (2018) who assert that the activities of terrorist groups like Boko Haram has caused untold hardships on those locations where their activities are prevalent in Nigeria and other neighboring countries like Cameroun and Chad.

Moreover, Ristoldo (2017) noted that the activities of ISIL (Islamic State of Iraq and the Levant) in 2015 destroyed so many ancient artifacts in Iraq. This is similar with the destruction of Afghan Bammiyan Buddhas in 2001 by the Talibans, and the popular attacks on the Sufi Mausoleums by Al Qaida affiliates in Mali in 2012. These activities have implications on heritage memory for the concerned socio-cultural groups in the affected communities (in Afghanistan and Mali). Ristoldo (2017) further noted that most of these cases of terrorist attacks on heritage are intentionally targeted to send a particular signal not minding the implications on identity, memory and socio-cultural 
lifestyle of the affected region. Hence, the need for a coordinated protection of heritage resources amidst armed conflicts and other attacks. Frey and Rohner (2007) supported the above assertions when they stated that many terrorist attacks in parts of the Middle East have been targeted on cultural monuments and other iconic monuments of great histories. They went further to state that attacks on these cultural relics of human history are carried out to get the attention of the government to respond positively and very fast to the demands of the groups.

Nimenibo et al. (2018) infer that militancy in the Niger Delta has affected communities in Bayelsa State more than other oil producing states in Nigeria. It has affected the socio-economic and other developmental strides as well as overall cultural regeneration, promotion and preservation. Abomaye et al. (2018) noted also that militancy in Niger Delta has negative impacts which includes loss of lives, unemployment and incessant business closures which has huge economic implications. In the same vein, Dialoke and Edeja (2017) worked on the effect of militancy in Niger Delta between 2006-2016 and noted that among these effects, are incidence of pipeline vandalization, kidnapping, attack on military personnel and facilities, loss of lives and properties, illegal oil bunkering, displacement and unrest among rural communities, etc. Olasupo (2013) is of the view that the militancy in Niger Delta is fueled by the poor economic condition and living standard of the people in the region. This is as a result of oil exploration and public neglect of the people. He went further to note that the crisis has effects not only on the economic lifestyle of the people, but also their socio-cultural lifestyle which has grossly been affected by the incessant state of unrest. This view is in line with the opinion of Moses and Olaniyi (2017) who added that the government should adopt peaceful dialogue with militants to curtail further damage on the socio-cultural and economic aspects of various communities that have been at the mercy of these attacks over the years.

Herdsmen attack is another destructive activity that ravages communal lifestyle in Nigeria. Tersooubwa, James and Bello (2018) noted that herdsmen crisis in Benue state is symmetric with cultural, structural and direct violence; stating causes of the crisis to include land scarcity, poor public policy, and herdsmen insistence on open grazing. They went further to note that the activities of herdsmen has caused great damage on farming system and freedom of expression of socio-cultural lifestyles among members of affected communities in their various communities (i.e., Idoma, Igede and Tiv communities, among others). This was equally supported by Abdulbarkindo, and Alupsen (2017) who concluded that herdsmen crisis has huge negative implications on the socioeconomic development of Benue and their neighboring states where herdsmen crisis has been reported in Nigeria.

From some other parts of the globe, it was reported that in Darfur region of Sudan, disputes between nomadic pastoralist herders and farmers over the migration routes 
for livestock and ownership of waterholes have escalated from mere agricultural disputes to cultural, ethnic and religious difference. This resulted to loss of lives, properties and natural resources including cultural heritage assets (Higueras, 2013; Brown \& Keating, 2015). Also, a village-level dispute in Afghanistan over land and irrigation water for farming was reported by a rural community survey in 2008 to have resulted in violent conflicts with attendant uprising in insurgency and coalition attacks with no regard for human lives and properties (Brow \& Keating, 2015). In addition, there have been incessant unresolved conflicts over land ownership in some localities in Liberia. This was as a result of loss of land record due to the protracted civil war in the country. Unnecessary tensions have been raised in these rural communities with unprecedented effects on agribusiness investments in those rural communities (Brown \& Keating, 2015). Finally, Keating (2015) noted that pressure on the available natural resources, has resulted to high resource conflicts in places like Burma, Sudan, Iraq, Libya, Afghanistan and Democratic Republic of Congo. Most of these wars were attributed to the struggle over the ownership of natural resources (Keating, 2015; Brown \& Keating, 2015; Smith et al., 2016).

The brief review above has been able to look at some kinds of resource conflicts and their consequential impacts on the nations, regions and communities. It also revealed that resource conflicts can have some negative effects on the heritage assets of a people. It is expected that at the end of this study, some notable resource conflicts and their impacts on the preservation of heritage assets in rural Nigeria, will be discussed.

\section{Resource Conflicts and Heritage Assets in Rural Nigeria}

The literature review in the previous section has been able to x-ray the contributory role of social stability in socioeconomic development of regions and the likes. The various variations of resource conflicts have not only been contributed to poor socioeconomic development but also to socio-cultural, religious and other values of various indigenous communities through heritage obliteration of all kinds. However, this aspect of the study investigates the various categories of resource conflict and their impacts on heritage assets in rural Nigeria.

\section{Herdsmen Crisis}

As noted earlier, this crisis has been as a result of quest for the outright use of land as natural resources. The Fulanis who are the predominant herders in Nigeria have engaged so many communities from different parts of the country on resource conflicts with scores of deaths recorded. The crisis has ravaged states like Enugu, Benue, Zamfara, Kaduna, Kogi, Adamawa, Delta among others. Many lives were lost, communities deserted for safety of human lives, comfort and peace of mind abused. In 2016, Nimbo community in Enugu state, and Agatu community in Benue state were seriously at- 
tacked, many rural dwellers were killed while others fled to surrounding communities. Shrines, sacred groves, community squares, traditional museums, among others were decimated. Indigenous festivals and dances were abandoned resulting to unnecessary fear and fluctuations in the calendar of such festivals. Also, long period of absence from traditional homes affects the sustainability and promotion of indigenous values. More so, in 2018 and 2019, communities like Jema'a, and Adara in Kujuru area of Kaduna State were attacked.

Moreover, Zumoso, Bang, Gon from Lamurde, Demsa and Numan communities in Adamawa state were decimated in 2018 and 2019. Village squares were destroyed; traditional rulers who are custodian of their customs and traditions were killed while some fled to refugee camps. Many traditional rites like naming ceremonies, rituals, indigenous festivals and other traditional celebrations were abused and abandoned. Notable shrines were seriously destroyed including traditional museums that were set up by these communities to preserve their history. In addition, Ajibefun (2017) noted that "...the killings recorded by Fulani herdsmen and farmers clash has rampaged most communities displacing them of their farmlands and loss of their major source of livelihood" (p. 134). He went further to note that most of the affected communities have lost their traditional communal lifestyles that are imbedded in their cherished culture and tradition. Bello (2013) supported this notion when he asserted that communities affected by herdsmen crisis in Northeastern Nigeria are in the state of socio-cultural and economic depletion, hence, the destruction of traditional and social structures that have been handed over through generations. The popular Durbar festival was among the victims of herdsmen crisis in Northeast Nigeria. Most of these festivals have been abandoned, some witnessed inconsistency in their circle of celebration and value, and some of them have their culture regalia and other materials destroyed, vandalized and looted.

\section{Boko Haram Crisis}

This could be said to be the deadliest insurgency movement in Nigeria that have destroyed lots of properties and lives, sacked communities from their original homes, rendered many people homeless, and turned many into refugees (Buhari \& Soetan, 2018; Eme \& Jide, 2012; Adejoh \& Aly, 2014; Anumudu, 2015; Asogwa, Eze, and Kelechi, 2015; Amalu 2015; Goyei, 2018). However, it is imperative to inform that Boko Haram (Jama'atu Ahhus Sunnah Lid Da'await wah Jihad) crisis has debased the Nigerian nation since the past two decades. It has decimated natural resources like water bodies, sacred groves, shrines, monuments, flora and fauna in affected communities in Northeastern Nigeria through unexpected explosions, shootings, and vandalization. This has greatly affected the socio-cultural and economic life of members of these rural communities (Eme \& Jide, 2012; Buhari \& Soetan, 2018). 
Many traditional festivals have not felt any good amidst incessant Boko Haram attacks in northeast Nigeria. For instance, in Yobe state, some traditional festivals have been grossly affected. A good example is the Kamti festival which is celebrated by the Ngamo people of the state to mark the end of the annual harvest. The festival is celebrated around September of every year among the clans, starting with Janga, the head of the clan. This festival does not only promote traditional values and communal living among the Nagmo people, it equally promotes agricultural practices, and hard work among the people. Series of Boko Haram attacks has affected the nature of the celebration of this festival. Visitors are now scared of taking part in the festival for fear of emergency attack from the insurgents. The Bade fishing and cultural festival is another festival that has been greatly affected in Yobe State since the emergence of Boko Haram. It is an annual celebration done among riverine communities in the state. Each of these communities have different names they call their own Bade fishing festival. For instance, it is called Idbizan in Damasa community, Fudan in Yin community, Kabbyon in Duwagaru community, among others. These festivals have lost their taste as visitors and participants have been discouraged by the activities of insurgents. The regularity and functionality of these festivals are currently hanging in the balance. Their activities were randomly disrupted by bomb blasts, shootings and kidnappings. Apart from Yobe state, traditional festivals have also been disrupted in Borno state, no thanks to Boko Haram insurgence. The festivals include the Durbar and Minwara festivals among others. Activities of these festivals have been disrupted between 2011 and 2017, even in the presence of security operatives. The festivals are gradually losing their traditional values and touristic features.

Also, some of the states in northeastern Nigeria have game reserves where special species of animals and plants are kept over the years either as totems, reserves or for touristic purposes. A good example is the Yankari game reserve in Bauchi state. Although the game reserve has not recorded any direct attack from the insurgent, but their activities are threats to peaceful coexistence in this reserve. The visitors' statistics have dropped drastically. The same is applicable to Falgore game reserve in Kano State, Kamuku National Park in Kaduna State, Kuyambana Game Reserve and Kwiambana Forest Reserve in Zamfara State, Chad basin National Park in Yobe and Bauchi States, Lame Burra Game Reserve in Gombe State, among others. Incessant sounds of bomb blasts from Boko Haram attacks have scared big games from these reserves, as well as reducing visitors' statistics since the last ten years. As such, the sustainability of the aforementioned sites and activities is under serious threat.

The reported destruction of Sukur World Heritage Site by the insurgents is a big blow on the heritage industry in Nigeria. In addition, many other sites and cultural activities in northeastern part of the country have been shunned by tourists and other visitors for fear of their lives and properties. They include but not limited to the Mambilla plateau, 
the palace of Emir of Kano, Uthman Danfodio tomb, Argungun fishing festival, among others. Also, some notable reserves like the Sambisa forest, a unique fauna and flora reserve, have lost its values to resource conflicts from Boko Haram insurgents (Eme \& Jide, 2012; Anumudu et al., 2015; Buhari \& Soetan, 2018).

\section{Militancy}

This is one of the crises that have almost crippled the Nigerian economy since the discovery of crude oil. It is as a result of the struggle for the ownership of crude oil in the Niger Delta region of the country. Crude oil is a rich mineral resource found in large quantity in South-South geopolitical zone of Nigeria otherwise referred to as Niger Delta region (Dialoke \& Edeja, 2017; Abomaye et al., 2018). The region houses various oil wells and pipelines alongside sophisticated oil facilities. The indigenous communities where these oil wells and explorations are located feel marginalized and hence, tends to control this mineral resource locally in their communities against the wishes of the government who explores and markets the oil. This struggle has taken its toll on the nation. Lives and properties worth billions of naira have been lost to this crisis as it involves vandalization of pipelines and other oil facilities estimated to cost over five trillion naira since the inception of the crisis in the late 1980's ((Dialoke \& Edeja, 2017; Abomaye et al., 2018). The bombardments, shootings, kidnappings and other instruments of war adopted by these militants have greatly obliterated the natural and cultural assets of the affected communities. These include water bodies, historical landscapes, traditional festivals, indigenous technology, fauna and flora among others.

It might interest you to know that even when these militant attacks are not targeted towards the members of the local communities and their properties, the consistency of their activities in the area is a nightmare for visitors who are part of the targets (Tersoubwa el al., 2018). Some of these communities have traditional festivals that have not only attracted tourists, but also promoted their indigenous values and culture identity beyond their boundaries. Some of these festivals includes the Sangbein Fishing Festival by Sagbama community, Okolode Festival by the Ekpetiama clan in Yenagoa, Ogoriba Uge Festival by Odi community in Kokokuma/Opokuma local government, Izogua Annual Festival by the Otuokpoti in Ogbia Local government, Ikpai-kpai Annual Festival by Ekowe community in Southern Ijaw, Igboruma War Canoe by Otuokpoti people in Ogbia, Iduangi Annual Festival by Nembe community in Nembe Local government and many others. These traditional festivals are losing their values as participants/visitors are lacking the needed motivation and for fear of militant-security clashes. Some other traditional festivals, historical landmarks and archaeological landscapes in other parts of the region like Rivers, Akaw-Ibom, Delta, etc., also suffer similar fate (Abara, nd.; Adejoh \& Aly, 2014; Buhari \& Soetan, 2018).

Regrettably, some great monuments in Niger Delta region have suffered threats from militancy attacks, while some have been physically vandalized, some are either affected 
by bomb blasts or abandoned by visitors and tourists. Some of the monuments that have suffered this fate from Akwa-Ibom include; 'Bridge of No Return' which was said to be an existing remnant of the horrors of slavery during the slave trade era in the region (it was used in the movement of slaves across Nigeria); the Ibibio Museum and State Park which is the embodiment of the peoples' culture and tradition has also been ravaged. Other affected monuments in Rivers State include Isaac Boro Park (a public outdoor recreation place built in honour of the pioneer of minority right activist in Nigeria, Isaac Boro); Port Harcourt Zoological Garden in Trans Amadi which was built in 1974 as one of the nation's conservation centres for fauna and flora; Port Harcourt cemetery which was said to contain the burials of some soldiers of the second world war and that of the renowned activist in the region-Ken Saro Wiwa and many others. These monuments and historical landscapes have embedded in them great histories the people cannot afford to lose to any form of resource wars.

Some notable water bodies like lakes, streams, rivers and waterfalls have also been decimated by contamination. Examples of such are the Ebe lake in Delta state, Lake Ukwa in Cross River State, Delta State Lake Park, just to mention a few. These are remarkable lakes in the area which has in them, great historical and tourism values (Ofuoke \& Isife, 2009; Olasupo, 2013).

\section{Banditry}

This is the most recent among resource conflicts that are currently ravaging the wealth and posterity of the nation. It was said to be as a result of the struggle for the ownership of special mineral resources like gold and the likes (Suleiman, 2019). This has affected states like Zamfara, Yobe, Kaduna, among others. It is regrettably to note that land resources and other traditional values of the affected communities in the above mentioned states have been abused by the activities of these armed bandits. For instance, Suleiman (2019) informs that some parts of northeast Nigeria have witnessed direct combat from different groups. There have been cases of kidnappings, attacks, abduction, killings, and robbery on the villagers, and travelers along major roads; they equally engage in cattle rustling.

Suleiman (2019) in his work identified the causes of this banditry from three schools of thought. The first attributed the cause to the quest for conquering land and grazing field for cows, the second attributed the cause to socioeconomic imbalance and other political factors. The third school of thought attributed it to the struggle for the control of gold deposits in the affected states for individual or group gold mining without any form of control from the government. No matter the dimension of cause, this crisis has unleashed untold hardship on the various indigenous communities in the affected areas. Heritage assets of these affected communities have equally suffered preservation and promotional setbacks amidst these conflicts. Banditry have ravaged most of the local 
communities in parts of Katsina, Zamfara, Kaduna states, among others, living many dead and some others injured. Over 10,000 houses and silos destroyed, rendering children homeless. This notion was equally affirmed by Suleiman (2019) when he informed that the local or indigenous lifestyles and activities have been dislodged owing to the activities of illegal miners in Zamfara State.

Moreover, indigenous festivals in Katsina like Gani of Daura; Kokowa (a traditional wrestling festival), Kalankuwa, Jaci and Sallah have been affected. These indigenous festivals have suffered continuity and faced preservation challenges in Katsina State. It is no more celebrated freely and active participants are gradually losing interest. This has huge implications for the preservation and sustainability of these traditional festivals. Also, the popular Durbi Takusheyi which is an ancient tomb in Katsina where past rulers have been buried since the $13^{\text {th }}$ century and an important archaeological landmark to the state, has been facing serious threats to its preservation and sustainability owing to the activities of armed bandits. These bandits sometimes threaten to destroy this ancient monument just to force the government to allow illegal gold mining in the state. This ancient landmark is monumental in the historical and archaeological reconstruction of ancient culture and tradition of the people of Katsina. There are some other heritage assets in Katsina, Zamfara, and Kaduna States that have been threatened by the activities of illegal gold miners in these states.

\section{Communal Conflicts}

Communal conflict in Nigeria has to do with all sorts of conflicts existing between two rural communities, in most cases. Land boundary dispute is the major cause of such conflicts (Osaretin, 2013; 0ji et al., 2014). Communal conflict has been identified as one of the challenges facing the socio-political landscape of Africa. It has both pre- and postindependence histories in most African countries. Nigeria as a nation is not exempted from the devastating effect of this category of resource conflict on heritage assets. For instance, since independence, Nigeria has suffered some notable communal conflicts which includes Yelwa-Shedam conflict (2003-2005), Itsekiri-Urhobo warri conflict (1999-2000), Ife- Modakeke crisis (1999-2000), Zango-Kataf conflict in Kaduna State (1999-2000), Ezillo and Ezza-Ezillo conflict (1982-2012), Tiv-Jukun Wukari conflict in Taraba state (1999-2001), etc. (see Oji et al., 2014). Others include Ndiowu/Ufuma crisis of 1998, Ajalli-Akpu crisis of 1990s, Aguleri/Umuleri crisis of 1990s, among others.

Communal conflicts is most of the time caused by disagreements on land boundaries by two or more communities, and sometimes caused by kingship tussles on who controls the traditional stool of a community or conglomeration of communities. Apart from the killings, other targets of this crisis are rich heritage assets of the affected community like shrines, streams, historical edifices, community squares, traditional celebrations, sacred groves, masquerade houses, worship centers, among others. The 
Ezza-Ezillo conflict in Ebonyi State saw the destruction of many shrines and historical edifices in the communities. Such was also the case with the Aguleri-Umuleri conflicts in Anambra State that destroyed some community squares, historical landmarks and burnt most traditional ornaments that are used in ritual practices and masquerading. The Akpu-Ajalli communal conflict in Anambra State affected the celebration of the popular Ikeji festival for two consecutive years likewise Ndiowu/Ufuma communal crisis. During these conflicts, masquerade houses were burnt, lives lost, community freedom lost, and a host of other negative implications.

However, during these crises, people from concerned communities were afraid to engage in their normal communal activities out of fear of being killed, injured or even kidnapped by the vandals of the opposing community. Another prominent crisis is the Jos crisis which is usually between indigenes and visitors over the control of the community assets or religious indifference. Osaretin (2013) also noted that these communal crises can also arise between a company/organization and the host community over disagreement on conditions of settlement. Even as crisis of this sort has arisen in time past, it has not been recorded to have resulted in the destruction of communal assets as witnessed in inter and intra communal crisis (Osaretin, 2013). The incessant community crisis in Jos has led to the suspension of celebration of some indigenous festivals and some other traditional ceremonies. All these does not only affect intangible heritage resources, as tangible resources like lakes, community squares, water bodies, ancient landmarks, just to mention a few, were also decimated.

\section{Theorization of Conflicts, Causes and Effects}

This study is theorized in Conflict Theory as was proposed by Karl Max in his co-authored book with Fredrick Engels, The Communist Manifesto, published in 1848). The summary of Karl Max's postulation in conflict theory is that the unending conflict in the society is a result of struggle over the control of the limited resources between the proletariat and the bourgeois. The bourgeois control the resources to maintain their ranks. Max further insinuates that these conflicts bring about change and development in the society. Moreover, the conflict theory has four major postulations: Competition (it is constant as a result of limited resources in the society), Revolution (it is the possible outcome of continued conflicts among the social classes), Structural inequality (human relations and social structures are products of inequalities, where some acquire more powers to suppress others), and finally war (it is seen as the ultimate end of conflicts in the society, either by way of unifying the society or cleansing the society).

However, the current study will be attempted to be mirrored within the context of the four major assumptions of conflict theory as postulated by Karl Max in 1848. On the first assumption which is Competition. Can we attribute the cause of resource conflicts in Nigeria to the competition between the proletariat and bourgeois? Militancy and in- 
surgency of bandits can be attributed to complaints and feelings of denial of due rights and privileges. In this case, conflict was seen as the way out not minding the extended implications. This may not be the same with conflicts like communal crisis, Boko Haram attack, and herdsmen attack; even when the conflict is focused on the ownership of a particular natural resource, the inequality factor is never an issue. So competition as a cause of conflict may not be completely applied in the Nigerian situation with respect to the sampled conflicts.

Moreover, on revolution as the result of continued conflict, it has limitations in the Nigeria situation. For instance, conflicts from militancy, Boko Haram and herdsmen can result to revolution as a result of ethnic bias. This informs the reasons for the incessant calls to contain these conflicts. Communal crisis and insurgency of bandits may not have such possibilities as a result of their nature, target and approaches. More so, the concept of structural inequality in conflict theory can be applied to the sampled conflicts. They are motivated by the feelings of having more power than others and the feelings of having fewer powers than others. Also the motivation of the assumed government support is also a factor in these conflicts. This can be used to annihilate others to regain natural resources or acquire natural resources. However, the structural inequality postulation in conflict theory by Karl Max helped in the understanding of the nature and motivation of conflicts among the sampled resource conflicts in Nigeria.

Furthermore, the last presumption of conflict theory has to do with 'war'. From the understanding of this postulation in conflict theory, it is obvious that all the sampled conflicts in Nigeria may not have the tendencies of resulting to war as a means of unifying or cleansing the society. Boko Haram, militancy and Herdsmen attack do have ethnicity prejudice and may have the tendencies of metamorphosing into war as last settlement option if not clutched at their current stages in the country. Resource conflicts like insurgency of bandits and communal crisis have minute probability of metamorphosing into war as a last resort due to their nature and targets. These last two conflicts concentrate on a limited land mass involving small traditional communities or rural areas. Finally, conflict theory propounded by Karl Max in 1848 is conceptualized in this study for the understanding of the nature and targets of the sampled resources conflicts in Nigeria. This knowledge is expected to help in finding a lasting solution to contain the sampled conflicts and at the same time, preserving the nation's rich heritage assets that are always at the mercy of these resource conflicts.

\section{Implications on heritage transfer and loss memories among rural population in Nigeria}

Heritage assets have been at the receiving end of these resource conflicts even when they may not have been the primary targets (Higueras, 2013; Thomas, 2015; Smith, et al., 2015; Omur, 2015; Lababidi \& Hiba, 2016). Uncontrolled resource conflicts have dealt decisively with huge heritage assets in rural Nigeria. Before long, undocumented 
cultural and natural heritage resources of places plagued with crisis/conflicts will be forgotten and this will pose a question on the identity of the people (Nwankwo et al., 2017). Just as in the case of the Sukur World Heritage Site in Adamawa State, where natural and cultural assets lost to Boko Haram can never be recovered (Obafemi, 2017). Most of these resource conflicts involve the destruction and vandalization of valuable cultural properties of rural communities. Intangible heritage practices like festivals, ritual practices, traditional ceremonies, indigenous values, among others, are lost, and these has far reaching implications for culture posterity.

Notably, traditional African societies place values on their traditional systems which are often transferred to the younger generation through myths, folklores, and other oral tradition media (Francis et al., 2011; Moustafa, 2016). Intangible heritage resources like festivals, ritual practices, indigenous culinary art, indigenous knowledge systems, traditional crafts and industries, cultural dances and the likes are grossly affected. While some of them are momentarily lost, most of them are perpetually lost to varying degrees of resource conflicts in the affected communities. What becomes of the knowledge of these irreplaceable intangible resources on the generations to come? How can the knowledge be transferred when most of the custodians are victims? Hence, the continuity of these heritage assets is greatly threatened by these conflicts. Various ethnic groups in Nigeria have their peculiar indigenous values and practices whose knowledge are gradually varnishing into thin air, no thanks to resource conflicts and some other factors like civilization, rural-urban migration, and materialistic lifestyles.

Same is applicable to the tangible heritage assets as they hold a lot of information about these traditional communities. They play significant role in historical reconstruction and archaeological landscape of these communities. Destruction of heritage assets leads to loss of sense of belonging with great question on communal identity. This is because the identity and purpose of these traditional communities are embedded in their peculiar heritage assets and the destruction of heritage is same as the destruction of communal identity (Nwankwo et al., 2017). Information on most traditional communities are most of the times elicited from these heritage assets (tangible and intangible) for academic, other related researches, and fact finding missions through participant observations in these communities.

Moreover, Akinnnade (1999) asserts that destruction of archaeological heritage and other historical evidence has huge negative implication on cultural information of extant societies. Likewise, distortion of archaeological and historical information owing to incomplete evidence as a result of resource conflicts creates unrecoverable gaps in historical reconstruction of extinct societies in the understanding of extant societies (Nwankwo \& Ukaegbu, 2011). Fragmented archaeological and historical data has huge implications on the cultural history of a people. Hence unchecked resource conflict can lead to the fragmentation of archaeological data. 
Furthermore, destruction of archaeological landscapes and historical landmarks of a people has implications for lost memory since they are the tell tales of human history. The decimation and abandonment of cultural activities and materials grossly affect continuities in their culture regeneration process. As such, future generation stands the risk of not having the knowledge of their existence. Sight, participation, myths, folklore, oral tradition and touch, has been identified as among the media of transmission for indigenous cultural practices and value systems of African communities (Williams \& Manunggurr, 1989; Stone, 1989; Sparkes, 1989; Ndagala \& Zengu, 1989; Mbunwe-Samba, 1989; Bello, 2000). However, the functionality of these media is currently being threatened by resource conflicts in several parts of Nigeria.

\section{Conclusion}

Identified resource conflicts include Boko Haram, militancy, herdsmen, banditry, and communal crisis. These conflicts have over the years affected the preservation of heritage assets in rural communities in Nigeria; even when heritage assets may not have been the targets of these resource conflicts, the effect is unimaginable. For instance, resource conflicts affected indigenous cultural practices, festivals, traditional value system, traditional dance, local cuisines, traditional arts and craft, indigenous knowledge and industry, shrines, forest reserves, sacred groves, lakes, rivers, streams, plants, animals among others in rural communities in Nigeria. This loss has great implications for lost memory since their knowledge of practice and existence is threatened. Destruction of these heritage assets creates a vacuum in rural cultural history with implications on culture sustenance and value reorientation. Heritage assets form bulk of the tourism assets in Nigeria with tendencies for economic transformation through tourism development (Nwankwo et al., 2017; Ezenagu, 2017; Tersooubwa et al., 2018). Heritage asset gives Nigeria and some other African nations, a comparative advantage over developed nations in world tourism market (Nwankwo, 2012). This has called for more responsive measures to clutch these conflicts.

However, resource conflicts can be addressed in four ways as noted by USIP (2007) and Brown and Keating (2015). These include using the existing management structures, following due legislative processes, engaging in judicial actions or court processes and lastly, exploring mediation or arbitration strategy. These processes can be followed sequentially for a better result. The international collaboration is the further suggestion from this study, and it needs to be explored after the four stages listed above have been exhausted. Most of the resource conflicts in Nigeria have exhausted the four stages with fewer results actualized. It is imperative to note that for an effective international collaboration, a range of skills are required for resolving resource conflicts. This include an understanding of the history of the conflict, history of the locality, political economy, knowledge of the natural resources, including resource governance, among others (Keating, 2015). However, with this understanding, international collaborations 
can be carefully explored to clutch resource conflicts, and with reasonable respect for the sovereignty of the nation involved. This is necessary because it was noted that an attempt to clutch resource conflicts in Nepal between 1996 and 2006 via international collaboration, failed because the international collaborators were not well equipped with the necessary information on the conflict and the people involved. For instance, the Maoist militants and the roles of India and China were neglected, with much regard given to the views of the Anglophones Nepalese elite. This effort by international collaboration failed because it lacked the needed integration of issues of social conflict and exclusion (see Brown \& Keating, 2015). A similar incidence took place in Ecuador when National Resources Defense Council (NRDC) intervened in the dispute between the Conoco oil company and the Huaorani people of the remote Oriente of Ecuador in 1991. During this intervention, it was reported that the Huaorani people were exclude from taking part in some private reconciliatory meetings. This raised some suspicions and the Huaorani people sought for outright withdrawal of NRDC from the conflict resolution process (Brown \& Keating, 2015).

That notwithstanding, these international organizations and NGO's need to develop a sustainable strategy before delving into resource conflict management in Nigeria to evade the kind of failures they recorded in places like Nepal between 1996 and 2006, and Ecuador in 1991 (Brown \& Keating, 2015). More so, the international collaboration can come in two ways; direct approach (that is bringing in the parties involved in a round table for discussion and dialogue) and indirect approach (that is creating an enabling environment for faster resolution of the conflict). The direct approach (which is the final) can be successful in the Nigeria situation if some factors are taken into consideration. For instance, the international collaborators or machineries need to be equipped with requisite knowledge and capacity building; consult, engage and convene relevant stakeholders in the conflict; regard the respective interests and values of these stakeholders; and finally support conflict resolution process to the conclusion (USIP, 2007; Brown \& Keating, 2015).

In conclusion, the business of clutching resource conflict should be taken more seriously in Nigeria than before to evade possibility of the last postulation of the conflict theory (War). To this regard, the assistance of international organizations and NGO's need to be requested by the government. The government has engaged in endless fights against these conflicts, with huge resources invested, but little was achieved. The Nigerian government may need to borrow a leaf from what happened in Papua Guinea, Central Asia, Timor-Leste, Liberia, and also helped in peaceful monitoring of the implementation of international peace agreements, among others. The 1954 UNESCO Convention on the Protection of Cultural Property in the event of Armed Conflict (popularly known as the Hague Convention) as reviewed in 1999, has a unique mandate to protect cultural properties during armed conflicts like the numerous resource conflicts in Nigeria. This convention can be explored by public cultural agencies in Nigeria like National Commission 
for Museums and Monuments (NCMM), Nigeria Tourism Development Commission (NTDC), Center for Black and African Arts and Civilization (CBAC), National Institute for Cultural Orientation (NICO), and other security agencies, to protect the nation's valued heritage assets in times of conflicts. Also the countries Nollywood industry (the maker of home movies), can also play a role in resource conflict resolution in Nigeria through making of related movies that would not condone the ills of resource conflicts through values reorientation and vital information on the politics of resource conflict in Nigeria. At the same time the role of the local community cannot be jettisoned (Collier, 2003). In addition, Janet (2011) had suggested that using a human right approach can help in cultural heritage protection during conflicts. This view may not apply in the Nigeria situation since the parties involved in these conflicts in Nigeria seems not to have reasonable regard for human right.

\section{References}

1. Abara, C. J. (n.d). The challenges of safeguarding and securing cultural heritage materials during violent conflict in Nigeria. Proceedings of the II International Conference on Best Practices in World Heritage: People and Communities, pp. 375-386. Retrieved from http://eprints.ucm.es/38838/1/.

2. Abdulbarkindo, A., \& Alupsen, B., (2017). Nigeria: Benue State under the shadow of "herdsmen terrorism" (2014-2016). Open Doors International / World Watch Research.

3. Abomaye, N., Williams, A. S., Abomaye, N., Tamunobarasinpiri, C. E., \& Iyerikabo, H. (2018). The activities of Niger Delta militants: A road map to development. Global Journal of Human Social Science; Economics 18(6), 45-60.

4. Adejoh, A. M., \& Aly, A.F. (2014). Evaluating the impact of Boko Haram terrorism on Yankari game reserve as a tourist resort in Bauchi state, Nigeria. IOSR Journal of Humanities and Social Science, 19(2), 57-61.

5. Adeloya, O. A., Labo, A., \& Penar, E. (2018). Public opinion on the root causes of terrorism and objectives of terrorists. A Boko Haram case study. Perspectives on Terrorism, 12(3), 35-49.

6. Ajibefun, M. B. (2017). Social and economic effects of the menace of Fulani herdsmen crisis in Nigeria. Journal of Education and Social Research, 8(2), 133-139.

7. Akinade, O. A., (1999). Illicit traffic in cultural property in Nigeria: Aftermaths and antidotes. African Study Monographs, 20(2), 99-107.

8. Amalu, N. S. (2015). Impact of Boko Haram insurgency on human security in Nigeria. Global Journal of Social Sciences, 14(1), 35-42. DOI: http://dx.doi.org/10.4314/gjss. v14i1.4.

9. Anozie, F. N. (2002). Archaeology of Igboland: The early prehistory. In G. E. K. Ofomata (Ed.), A survey of the Igbo Nation (pp. 13-23). Africana First Publishers.

10. Anumudu, C. N., Asogwa, I. S., Eze, O. J., \& Kelechi, A. (2015). Boko-Haram crisis and implications for development in the northern Nigeria. International Journal of Economics, Commerce and Management, 3(4), 1-12. 
11. Bello, S. (2000). Africa's culture as basis for its technological development. In S. Bello (Ed.), Something to hold on to: Essays on culture, creativity and development. National Council for Arts and Culture.

12. Bello, A. S. (2013). Herdsmen and farmers conflict in Northeastern Nigeria: causes, repercussions and resolutions. Academic Journal of Interdisciplinary Studies, 2(5), 29-139.

13. Brown, 0., \& Keating, M. (2015). Addressing natural resource conflicts: Working towards more effective resolution of national and sub-national resource dispute. Energy, Environment and Resources. CHATHAM HOUSE: The Royal Institute of International Affairs.

14. Buhari, L. O., \& Soetan, O. S., (2018). Interrogating the impact of Boko Haram insurgence on the cultural and natural heritage protection in northern Nigeria. International Journal of Humanities Social Sciences and Education, 5(10), 145-151.

15. Collier, P. (2003). The market for civil war. Foreign Policy, 136, 38-45.

16. Dialoke, I., \& Edeja, M. (2017). Effects of Niger Delta militancy on the economic development of Nigeria (2006-2016). International Journal of Social Sciences and Management Research 3(3), 25-36.

17. Eme, O. I., \& Jide, I. (2012). The cost of Boko Haram activities in Nigeria. Arabian Journal of Business and Management Review, 2(2), 10-32.

18. Ezenagu, N. (2018). Challenges of tourism promotion in Nigeria: The case of religion. African Journal of Hospitality, Tourism and Leisure, 7(1), 1-18.

19. Francis, P., LaPin, D., \& Rossiasco, P. (2011). Securing development and peace in the Niger Delta. Woodrow Wilson International Center for Scholars in African Programme.

20. Frey, B. S., \& Rohner, D. (2007). Protecting cultural monuments against terrorism. Defence and Peace Economics, 18(3), 245-252.

21. Goyei, F. G. (2018). Nigeria's Boko Haram and its security dynamics in the West African sub-region. Journal of Language, Technology and Entrepreneurship in Africa $9(1), 102-131$.

22. Higueras, A. (2013). Aid and reconstruction of heritage in the context of post-conflict societies. Archaeologies, 9(1), 91-105.

23. Janet, B. (2011). Taking a Human Right approach to cultural heritage protection. Heritage and Society, 4(2), 199-238.

24. Max, K., \& Engels, F. (1848). The communist manifesto. Workers Educational Association.

25. Keating, M. (2015). How do resources create conflicts? World Economic Forum. Retrieved from https://www.weforum.org/agenda/2015/08/how-do-resources-cre ate-conflict/.

26. Klare, M. T., Levy, B. S. \& Sidel, V. W. (2011). The public health implications of resource wars. American Journal of Public Health, 101(9), 1615-1619.

27. Lababidi, R., \& Hiba, Q. (2016). Did they really forget it? Irag, Syria, and the international response to a shared heritage. Journal of Eastern Mediterranean Archaeology and Heritage Studies, 4(4), 341-362. 
28. Mohammed, D. (2014). The effect of Boko Haram crisis on socio-economic activities in Yobe State. The International Journal of Social Sciences and Humanities Invention, 1(4), 251-257.

29. Moses, D., \& Olaniyi, A. T. (2017). Resurgence of militancy in the Niger Delta Region of Nigeria. Journal of Political Science and Public Affairs, 5(4), 1-6. DOI: 10.4172/23320761.1000298.

30. Mbunwe-Samba, P. (1989). Oral tradition and the African past. In R. Layton (Ed.), Who needs the past? Indigenous values and Archaeology (pp. 106-117). Unwin Hyman.

31. Moustafa, L. H., (2016). Cultural heritage and preservation: Lessons from World War II and the contemporary conflict in the Middle East. The American Archivist, 79(2), 320338. DOI: https://doi.org/10.17723/0360-9081-79.2.320.

32. Ndagala, D. K., \& Zengu, N. (1989). From the raw to the cooked: Haddzabe perceptions of their past. In R. Layton (Ed.), Who Needs the Past?: Indigenous Values and Archaeology (pp. 51-54). Unwin Hyman.

33. Nimenibo, A., Samel, W. A., Nimenibo, A., Emmanuel, C. T., \& Iyerikabo, H. (2018). The activities of Niger Delta militants: A road march to development. Global Journal of Human Social Science E-economics, 18(6), 45-61.

34. Nwankwo, E. A. (2012). Sustainable heritage management in Nigeria for tourism development. Nsukka Journal of Humanities, 20, 115-124.

35. Nwankwo, E. A. (2013). Safety and security measures in the heritage industry of the Eastern Region of Nigeria. An unpublished PhD Dissertation, University of Nigeria Nsukka.

36. Nwankwo, E. A., Anozie, 0. 0., \& Obieluem, U. H. (2017). Sustainable safety and security at museums in Southeast Nigeria: implications for national Reformation. International Journal of Tourism Anthropology, 6(1), 62-84.

37. Nwankwo, E. A., \& Ukaegbu, M. O. (2011). The past and the society: Towards a sustainable tourism development. Nsukka Journal of Humanities, 19, 155-166.

38. Obafemi, A. P. O. (2017). World heritage sites and armed conflicts: A case of Sukur Cultural Landscape and Boko Haram insurgency in Nigeria. Proceedings of the Fourth International Conference on Heritage Conservation and Site Management (pp.161-170).

39. Ofomata, G. E. K. (2002). The natural resources of Igboland: The geopolitical dimension in contemporary Nigeria. In G.E.K. Ofomata (Ed.), A survey of the Igbo Nation (pp. 644-656). Africana First Publishers.

40. Ofuoke, A. U., \& Isife, B. I. (2009). Causes, effects and resolution of farmers-nomadic herders conflict in Delta state Nigeria. International Journal of Sociology and Anthropology, 1(2), 47-54.

41. Oji, R. O., Eme, O. I., \& Nwoba, H. A. (2014). Communal conflicts in Nigeria: an examination of Ezillo and Ezza-ezillo conflict of Ebonyi state. Kuwait Chapter of Arabian Journal of Business and Management Review, 4(1), 514-526.

42. Olasupo, O. (2013). The consequences of militancy in Nigeria's Niger Delta. JORIND, 11(2), 149-157. 
43. Omur, H. (2015). ISIS, heritage, and the spectacles of destruction in the global media. Near Eastern Archaeology, 78(3), 170-177.

44. Osaretin, I. (2013). Corporate community crisis in Nigeria: causes and consequences; case study of Presco industries and Oghareki community. IOSR Journal of Humanities and Social Science, 15(1), 22-29.

45. Paki, F.A.E., \& Ebienfa, K. I. (2011). Militant oil agitations in Nigeria's Niger Delta and the economy. International Journal of Humanities and Social Sciences, 1(5), 140-145.

46. Ristoldo, F. (2017). Attacks against cultural property as a weapon of war: An exploratory case study. An unpublished master's project, Institut Barcelona Estudis Internationals.

47. Smith, C., Heather, B., Cherrie, L., \& Gary, J. (2016). The Islamic States symbolic war: Dae'sh's socially meditated terrorism as a threat to cultural heritage. Journal of Social Archaeology 16(2), 164-188.

48. Sparkes, B. (1989). Classical Greek attitudes to the past. In R. Layton (Ed.), Who Needs the Past? Indigenous Values and Archaeology (pp. 119-130). Unwin Hyman.

49. Stone, P. G. (1989). Interpretation and uses of the past in Modern Britain and Europe. Why are people interested in the past? Do the experts know or care? A plea for further study. In R. Layton (Ed.), Who Needs the Past? Indigenous Values and Archaeology (pp. 195-206). Unwin Hyman.

50. Suleiman, S., (2019, June 13). Rural banditry in Zamfara State, northwest Nigeria. Kujenga Amani. Retrieved https://kujenga-amani.ssrc.org/2019/06/13/rural-ban ditry-in-zamfara-state-northwest-nigeria/.

51. Tersooubwa, K., James, J. N., \& Bello, O. (2018). Political economy of herdsmen/farmers' conflict in Benue state 2008-2018. International Journal of Education and Research, 6(6), 131-142.

52. Thomas, F. (2015). Heritage erasure and heritage transformation: How heritage is created by destruction in Bahrain. International Journal of Heritage Studies, 21(4), 390-404.

53. Ubkwa, K. T., James, J. N., \& Ohianil, B. (2018). Political economy of herdsmen/famers' conflict in Benue state 2008-2018. International Journal of Education Research, 6(6), 131-142.

54. USIP. (2015). National resources, conflicts, and conflict resolution. USIP.

55. Williams, N. M., \& Manunggurr, D. (1989). Understanding Yolngu signs of the past. In R. Layton (Ed.), Who needs the past?: Indigenous Values and Archaeology (pp. 70-83). Unwin Hyman. 